\title{
Silica production and the contribution of diatoms to new and primary production in the central North Pacific
}

\author{
Mark A. Brzezinski ${ }^{1, *}$, Tracy A. Villareal ${ }^{2}$, Fredric Lipschultz ${ }^{3}$ \\ ${ }^{1}$ Marine Science Institute and the Department of Ecology Evolution and Marine Biology, University of California, \\ Santa Barbara, California 93106, USA \\ ${ }^{2}$ The University of Texas at Austin, Marine Science Institute, 750 Channel View Drive, Port Aransas, Texas 78373-5015, USA \\ ${ }^{3}$ Bermuda Biological Station for Research, Ferry Reach GE 01, Bermuda
}

\begin{abstract}
The silica cycle in the upper $200 \mathrm{~m}$ of the central North Pacific was examined to further assess the role of oligotrophic mid-ocean gyres in the global marine silica cycle and to evaluate the role of diatoms in the regional carbon and nitrogen cycles. Siliceous biomass in the upper $200 \mathrm{~m}$ was very low (generally $<50 \mathrm{nmol} \mathrm{Si} l^{-1}$ of biogenic silica) with higher concentrations (100 to $280 \mathrm{nmol} \mathrm{Si} l^{-1}$ ) observed occasionally in the deep chlorophyll maximum and in the nitracline. Doubling times for biogenic silica were generally between 2 and 5 d, suggesting fairly rapid diatom growlh. Kintic experiments showed widespread limitation of silica production rates by ambient silicic acid concentrations $(0.9$ to $3.0 \mu \mathrm{M}$ ). Inputs of iron inferred from high concentrations of lithogenic silica (up to $300 \mathrm{nmol} \mathrm{Si} \mathrm{l}^{-1}$ ) in surface waters did not stimulate silica production. Integrated silica production rates averaged $1.24 \mathrm{mmol} \mathrm{Si} \mathrm{m} \mathrm{m}^{-2} \mathrm{~d}^{-1}$ (range 0.47 to $2.9 \mathrm{mmol} \mathrm{Si} \mathrm{m}^{-2} \mathrm{~d}^{-1}$ ). This average is 2 to 3 times higher than those reported for other oligotrophic mid-ocean gyres, significantly increasing estimates of the fraction of global silica production occurring in these systems. A pronounced diatom bloom dominated by Mastogloia woodiana and Hemiaulus hauckii was observed ca $200 \mathrm{~km}$ north of the Joint Global Ocean Flux Study (JGOFS) Hawaii Ocean Time-series (HOT) site in August 1995. A doming of isopycnals within the nutricline beneath the bloom suggested the presence of a cyclonic eddy that was enhancing local

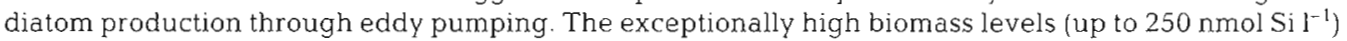

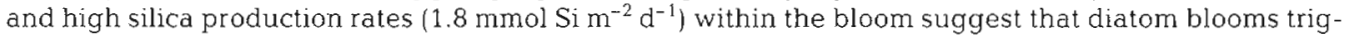
gered by the mesoscale flow field may contribute significantly to regional silica production. Diatom primary production in the central North Pacific estimated from the overall average integrated silica production rate and diatom Si:C ratios is $9.5 \mathrm{mmol} \mathrm{C} \mathrm{m} \mathrm{Cl}^{-2} \mathrm{~d}^{-1}\left(=114 \mathrm{mg} \mathrm{C} \mathrm{m} \mathrm{m}^{-2} \mathrm{~d}^{-1}\right)$, which is $25 \%$ of the average primary productivity at the JGOFS HOT site. Silicic acid and nitrate supply rates to the euphotic zone inferred from the gradients of the 2 solutes in the nutricline are in about the same proportion as diatom cellular Si: $\mathrm{N}$ ratios. Thus, net consumption of the silicic acid supplied to the surface layer requires that diatoms account for a significant fraction of new production in the central North Pacific.
\end{abstract}

KEY WORDS: Diatoms $\cdot$ Elemental cycles $\cdot$ New production $\cdot$ Silica cycling $\cdot$ Silicon

\section{INTRODUCTION}

The role of diatoms and other large phytoplankton in open ocean biogeochemical cycling received relatively little study after the discovery of abundant picoplankton (Waterbury et al. 1979) focused attention on

-E-mail: brzezins@lifesci.ucsb.edu the role of small cells in pelagic food webs. Picophytoplankton and bacterioplankton are now known to dominate microbial biomass and primary productivity in the open sea (e.g. Cho \& Azam 1990). The bulk of the carbon fixed by picophytoplankton is respired by the relatively long food chains of the microbial loop (Azam et al. 1983), leading to low rates of particulate organic carbon export from that food web (Michaels \& Silver 1988). Recent observations suggest that the 
export of particulate carbon is predominantly mediated by large phytoplankton and by diatoms in particular (e.g. Sieracki et al. 1993, Honjo et al. 1995. Smith et al. 1996, Dugdale \& Wilkerson 1998).

Goldman (1988) reiterated the idea that a single large diatom cell has a biomass equal to well over a million cyanobacteria and has a much faster sinking rate, so that large cells are exported from surface waters preferentially. Large diatoms also have the ability to rapidly take up pulses of nitrate, allowing them to exploit nutrient pulses during episodic mixing (Goldman 1993). Studying such large rare cells in nature is logistically difficult, and arguments as to their importance in elemental cycles were first based on experiments with cultures (Goldman 1993) and theoretical calculations (Goldman 1988) rather than on evidence from natural plankton assemblages. Notable exceptions are field studies of mats of diatoms of the genus Rhizosolenia that migrate to the nitracline to obtain nitrate (Villareal et al. 1993). The vertical transport of nitrate by those organisms enhances the upward flux of nitrate in the central North Pacific (Villareal et di. 1993, Vijiareal et al. 1996) and may contribute to a deficit in preformed nitrate at the base of the euphotic zone in this region (Emerson \& Hayward 1995).

Empirical evidence from several recent field programs confirms that diatoms are important to new and export production in several oceanic habitats. Diatoms had a major role in both new and export production during the Joint Global Ocean Flux Study (JGOFS) process studies in the North Atlantic and in the equatorial Pacific. Diatoms dominated the vernal bloom in the JGOFS North Atlantic Bloom experiment, leading to the depletion of silicic acid before nitrate (Sieracki et al. 1993). The consequent limitation by Si may have lead to the aggregation and rapid export of the bloom to depth (Sieracki et al. 1993). The rapid export of large cells has also been confirmed in the equatorial Pacific where large flocs of relatively fresh phytoplankton, mainly large diatoms, were observed covering an extensive area of the sea floor at depths $>4000 \mathrm{~m}$ (Smith et al. 1996). Time-series sediment trap studies in the same region show that pulses of particulate organic carbon (POC) and biogenic silica export occur simultaneously, implying an important role for diatoms in carbon flux (Honjo et al. 1995).

Diatoms have also been shown to be important to new and export production at both US JGOFS timeseries sites. The flux of POC at the Hawaii Ocean Timeseries (HOT) site displays a distinct summer maximum coincident with the annual maximum in the flux of diatom silica (Karl et al. 1996). Studies of silica production and export at the Bermuda Atlantic Time-series (BATS) site and other sites in the northwestern Sargasso Sea indicate that diatoms account for 13 to $26 \%$ of annual pri- mary production and 16 to $40 \%$ of annual new production (Brzezinski \& Nelson 1995, Brzezinski \& Kosman 1996, Nelson \& Brzezinski 1997). A similar result was obtained in the western equatorial Pacific by Blain et al. (1997), who estimated that diatoms account for a third of primary productivity in that region.

The importance of diatoms to the biogeochemistry of the open sea elevates the significance of silicic acid as a key nutrient regulating biogeochemical cycling in offshore waters. Unlike other phytoplankton, diatoms have an obligate Si requirement for growth (Lewin 1962). The availability of dissolved Si has been shown to control diatom silica production rates, at least at times, in every natural system examined to date (Nelson et al. 1976, Nelson \& Brzezinski 1990, Nelson \& Tréguer 1992, Brzezinski \& Nelson 1996, Nelson \& Dortch 1996). Limitation of diatom metabolism by the supply rate of silicic acid results in a physiological cascade that affects diatom primary productivity and nitrogen use (Dugdale et al. 1981), potentially altering regional nitrogen and carbon cycling. For example, the supply rate of silicic acid to diatoms has been hypothesized to control the level of primary productivity and new production in the equatorial Pacific ( $\mathrm{Ku}$ et al. 1995, Dugdale \& Wilkerson 1998).

Field experiments examining diatom silica production and new production are relatively few, but the extensive database of upper-ocean nutrient profiles provides evidence as to the general importance of diatoms for oceanic new production. The gradient in silicic acid within the nutricline throughout much of the ocean equals or exceeds that for nitrate (Kamykowski \& Zentara 1985), such that mixing supplies at least as much silicic acid to the surface ocean as it does nitrate. That supply rate ratio of silicic acid:nitrate nearly equals the Si: $\mathrm{N}$ mole ratio within diatoms ( $\mathrm{Si}: \mathrm{N}$ $=0.8$; Brzezinski 1985), suggesting that net depletion of the silicic acid in surface waters consumes a large fraction of the nitrate supply, resulting in a significant fraction of new production being carried out by diatoms. Dugdale \& Wilkerson (1998) confirmed this expectation for the equatorial Pacific, showing that silicic acid and nitrate are depleted in a mole ratio of $1: 1$ as upwelled waters advect poleward, and hypothesized that new production is largely regulated by the supply of silicic acid to diatoms in that system. The general conclusion to be drawn from the accumulating evidence is that there are stronger links between the silica cycle and those of carbon and nitrogen in the open sea than previously realized.

Studies of the silica cycle of mid-ocean gyres have been confined to the Sargasso Sea (Brzezinski \& Nelson 1995, Brzezinski \& Kosman 1996, Nelson \& Brzezinski 1997). Siliceous biomass is very low in that system (generally $<50 \mathrm{nmol} \mathrm{Si}^{-1}$ ) and biogenic silica 
concentrations remain $\leq 580 \mathrm{nmol} \mathrm{Si}{ }^{-1}$ even during diatom blooms (Brzezinski \& Nelson 1995). The Sargasso Sea is unusual in that the concentrations of silicic acid, nitrate and orthophosphate do not vary in Redfield proportions within the nutricline, resulting in a nearly 4 -fold deficit in the supply rate of silicic acid to the euphotic zone compared to the expected Si:N:P mole ratio of 16:16:1 (Brzezinski \& Nelson 1996). Si regulation of silica production is pervasive, as substrate limitation of silica production has been observed during all seasons over 2 yr in conjunction with chronically low silicic acid concentrations $(0.7 \pm 0.2 \mu \mathrm{M}$; Brzezinski $\&$ Nelson 1996). Even under these Si limiting conditions, diatoms account for 16 to $40 \%$ of new production in that system (Brzezinski \& Nelson 1995, Brzezinski \& Kosman 1996, Nelson \& Brzezinki 1997).

It is difficult to extrapolate the results from the Sargasso Sea to other mid-ocean gyres. The increase in silicic acid concentration across the seasonal nutricline in the Sargasso is small compared to other systems. These differences are pronounced between the North Atlantic (Sargasso Sea) and the North Pacific, which lie at opposite ends of the global ocean thermohaline circulation (Broecker 1991, Macdonald \& Wunsch 1996). Surface waters of the Sargasso Sea typically contain $0.7 \pm 0.2 \mu \mathrm{M} \mathrm{Si}(\mathrm{OH})_{4}$ with only slightly higher concentrations $(1.5 \mu \mathrm{M})$ present in the underlying $18^{\circ} \mathrm{C}$ water mass between 200 and $450 \mathrm{~m}$ (Brzezinski \& Nelson 1995). In contrast, silicic acid concentrations in the surface waters of the central North Pacific are about 1 to $3 \mu \mathrm{M}$ (Craig et al, 1981) increasing to $>5$ $\mu \mathrm{M}$ by $200 \mathrm{~m}$ compared to the $<1 \mu \mathrm{M}$ increase in $\left[\mathrm{Si}(\mathrm{OH})_{4}\right]$ over that depth range in the Sargasso Sea. The increased silicic acid supply rates in the Pacific implied by these comparisons suggest that, all other things being equal, silica production in the central North Pacific should be greater than in the Sargasso Sea.
We have conducted the first examination of silica production in the central North Pacific using modern tracer methods. Our goals were to examine silica production rates across a large area within the gyre for comparison with results from the Sargasso Sea and to examine the role of silicic acid in regulating diatom silica production and the contribution of diatoms to upper water column carbon and nitrogen cycling.

\section{METHODS}

Two cruises were conducted to examine the silica cycle of the central North Pacific gyre. Seventeen stations between $23-31^{\circ} \mathrm{N}$ and $159-175^{\circ} \mathrm{W}$ were occupied from August 5 to 23, 1995. These stations were subdivided into 2 groups of sequentially occupied stations approximating a northern and a southern transect along ca $27.5^{\circ} \mathrm{N}$ and $25.5^{\circ} \mathrm{N}$, respectively (Fig. 1). The first station occupied was on the eastern end of the northern transect. Once the northern transect was completed, the southern transect was initiated at its western terminus. Fourteen additional stations between $24-32^{\circ} \mathrm{N}$ and $158-127^{\circ} \mathrm{W}$ were occupied between July 17 and 31, 1996 (Fig. 1) beginning with a station $60 \mathrm{~km}$ north of station $\triangle$ LOHA of $\mathrm{Hawaii,} \mathrm{USA.}$ Sampling proceeded northward to $30^{\circ} \mathrm{N}$ and then east, forming a transect line along ca 30 to $31^{\circ} \mathrm{N}$ (Fig. 1 ).

Water samples were collected before dawn at each station from 9 depths corresponding to $100,54,35,16$, $7.0,3.6,1.7,0.6$, and $0.1 \%$ of the irradiance measured just below the sea surface, $I_{0}$. Water samples were collected using acid-cleaned 101 Niskin bottles hung on Kevlar line during the 1995 cruise and mounted on a plastic-coated rosette during 1996. Conductivity/temperature/depth (CTD) profiler data was collected using a Seabird 9/11 Plus CTD attached to the rosette during 1996 and lowered on a separate cast within 30 min of

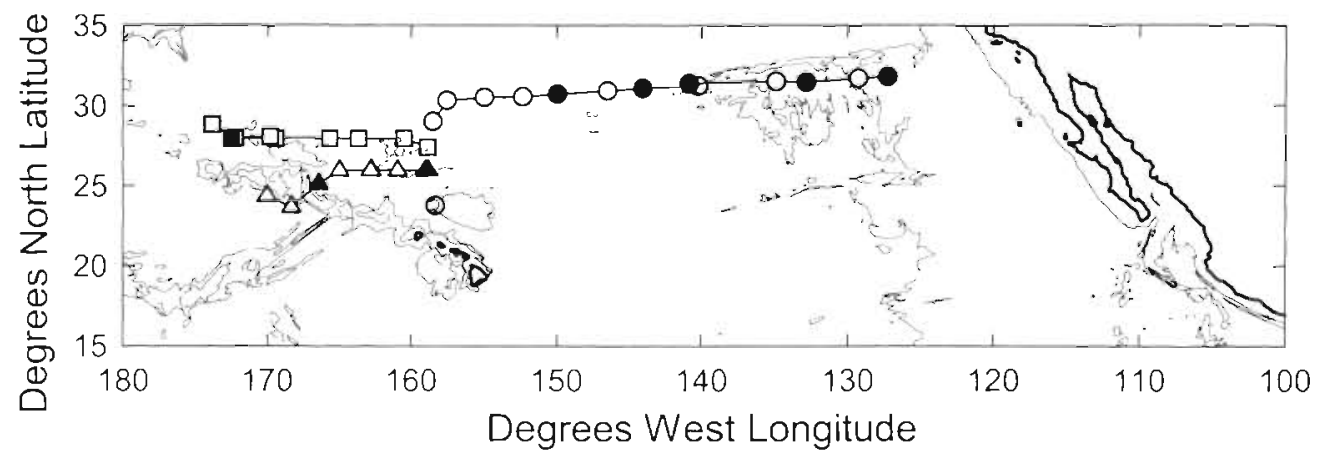

Fig. 1. Stations locations in the central North Pacific. Stations linked by solid lines were grouped to form a southern and northern transect in August 1995 (triangles and squares, respectively) and a transect along approximately $31^{\circ} \mathrm{N}$ in July 1996 (circles). Filled symbols denote locations where kinetic experiments to examine the dependence of silica production on [Si(OH) ${ }_{4}$ ] were performed. Bathymetry contours correspond to 3000 and $4500 \mathrm{~m}$ 
the Go-Flo casts in 1995. Physical data were merged into $1 \mathrm{~m}$ depth bins for analysis. Each Niskin bottle was completely drained through silicone tubing into $10 \mathrm{l}$ polypropylene carboys. Subsamples for all measurements were drawn from the carboys with frequent agitation to keep particles in suspension.

Chlorophyll concentrations were determined fluorometrically (Welschmeyer 1994) with a Turner Designs 10 AU fluorometer calibrated with pure chlorophyll $a$ (Sigma Chemical Co.). Nitrate concentrations were determined using the Yoshizumi et al. (1985) modification of the chemoluminescence technique of Garside (1982) configured to have a detection limit of $2 \mathrm{nM}$ $\mathrm{NO}_{3}{ }^{-}$. Ambient silicic acid concentrations were measured using a modification of Strickland \& Parsons (1972) that employs the reagent blank of Brzezinski \& Nelson (1986) yielding a detection limit of $50 \mathrm{nM}$ $\mathrm{Si}(\mathrm{OH})_{4}$. A 2.8 l subsample was drawn for combined biogenic and lithogenic silica concentration analysis and processed as described by Brzezinski \& Nelson (1989) with detection limits of $0.2 \mathrm{nmol} \mathrm{Si} \mathrm{^{-1 }}$ for both analyses.

Silica production rates were measured using ${ }^{32} \mathrm{Si}(\mathrm{OH})_{4}$ tracer Samples for silica production rate determinations were drained from the carboys into $320 \mathrm{ml}$ square polycarbonate bottles and $1.11 \mathrm{kBq}$ of a ${ }^{32} \mathrm{Si}\left[42\right.$ to $50 \mathrm{kBq}(\mu \mathrm{g} \mathrm{Si})^{-1}$ ] was added to each. All stock solutions of ${ }^{32} \mathrm{Si}$ were passed through Chelex resin to remove trace metals. The addition of the tracer increased the ambient silicic acid concentration by ca $1 \mathrm{nM}$. Then each subsample was placed in an acrylic deck incubator equipped with flowing seawater to maintain temperature. Neutral density screens were used to simulate the ambient light intensity at the depth of collection. Incubations lasted $12 \mathrm{~h}$. At the end of each incubation, the particulate matter in each incubation bottle was collected by vacuum filtration $(<15 \mathrm{~cm} \mathrm{Hg}$ vacuum) onto a $25 \mathrm{~mm}, 0.6 \mu \mathrm{m}$ polycarbonate filter and then rinsed 3 times with filtered seawater to wash away excess tracer. The filters containing the particulate material were each placed flat in the bottom of a plastic scintillation vial, dried overnight in air, and the vials capped. The amount of radioactivity from ${ }^{32} \mathrm{Si}$ in each sample was determined back in the laboratory using a Beckman LS5000 TA liquid scintillation counter. Counting methods and the calculation of silica production rates followed Brzezinski \& Phillips (1997).

Experiments to examine the kinetics of silica production as a function of substrate availability were conducted at 3 stations during 1995 and 5 stations during 1996 located as indicated in Fig. 1. For each experiment, seawater was collected from $50 \% I_{0}$ and drained into a 101 polypropylene carboy as described above. Then eight $320 \mathrm{ml}$ subsamples were drained from the carboy into polycarbonate bottles. One subsample was immediately processed for biogenic silica concentration analysis as described above. A gradient in silicic acid concentration from 0 up to ca $20 \mu \mathrm{M} \mathrm{Si}(\mathrm{OH})_{4}$ above ambient was created in the remaining 7 subsamples by the addition of an aqueous solution of sadium metasilicate that had been passed through Chelex resin to remove trace metals. Then $1.11 \mathrm{kBq}$ of the ${ }^{32} \mathrm{Si}(\mathrm{OH})_{4}$ stock was added to each bottle and the samples mixed and incubated in the deck incubators at $50 \% I_{0}$ for no more than $12 \mathrm{~h}$ before processing as described above for silica production rate samples.

The response of the specific rate biogenic silica production, $V_{b}$, to increasing $\mathrm{Si}(\mathrm{OH})_{4}$ availability was examined using the Michaelis-Menten equation

$$
V_{\mathrm{b}}=\frac{V_{\mathrm{m}}\left[\mathrm{Si}(\mathrm{OH})_{4}\right]}{K_{\mathrm{s}}+\left[\mathrm{Si}(\mathrm{OH})_{4}\right]}
$$

where $V_{\mathrm{m}}$ is the specific silica production rate at infinite $\left[\mathrm{Si}(\mathrm{OH})_{4}\right]$ and $K_{\mathrm{S}}$ is the half-saturation constant defined as the $\left[\mathrm{Si}(\mathrm{OH})_{4}\right]$ that supports a specific production rate equal to $0.5 V_{\mathrm{m}}$. The data from each kinetic experiment were fitted to Eq. (1) using non-linear regression employing the Marquardt-Levenberg algorithm (Press 1992).

\section{RESULTS}

\section{Physical characteristics}

In 1995 , surface layer temperatures were $>26^{\circ} \mathrm{C}$ across most of the southern section with water temperatures decreasing to $24-26^{\circ} \mathrm{C}$ along the northern transect. Surface temperatures along the 1996 transect were 22 to $25^{\circ} \mathrm{C}$. Salinity generally decreased with depth in all 3 transects (Figs. 2 to 4 ), indicating the presence of the shallow seasonal salinity minimum previously reported in the central North Pacific during summer between $130^{\circ}$ and $170^{\circ} \mathrm{W}$ (Reid 1973). The base of the euphotic zone as defined by the depth where irradiance decreased to $1 \% I_{0}$ was between 100 and $120 \mathrm{~m}$ at all stations (data not shown).

In both years the pycnocline was much shallower than the $1 \%$ light level. In 1995, the seasonal pycnocline was located between 50 and $60 \mathrm{~m}$ across most of the southern section (Fig. 2) and shoaled to $30-50 \mathrm{~m}$ in the northern section (Fig. 3). In 1996 the pycnocline was again located between 30 and $50 \mathrm{~m}$ to the east of $135^{\circ} \mathrm{W}$ (Fig. 4). A strong lateral gradient in salinity at 130 to $135^{\circ} \mathrm{W}$ marked the transition from the gyre to the California Current (Fig. 4).

Significant localized doming of isopycnals was observed in 1995. A pronounced feature was observed in the southern section at $159^{\circ} \mathrm{W}$, where the 25.5 isopycnal shoaled to $<200 \mathrm{~m}$ (Fig. 2). Shoaling of the 25.5 

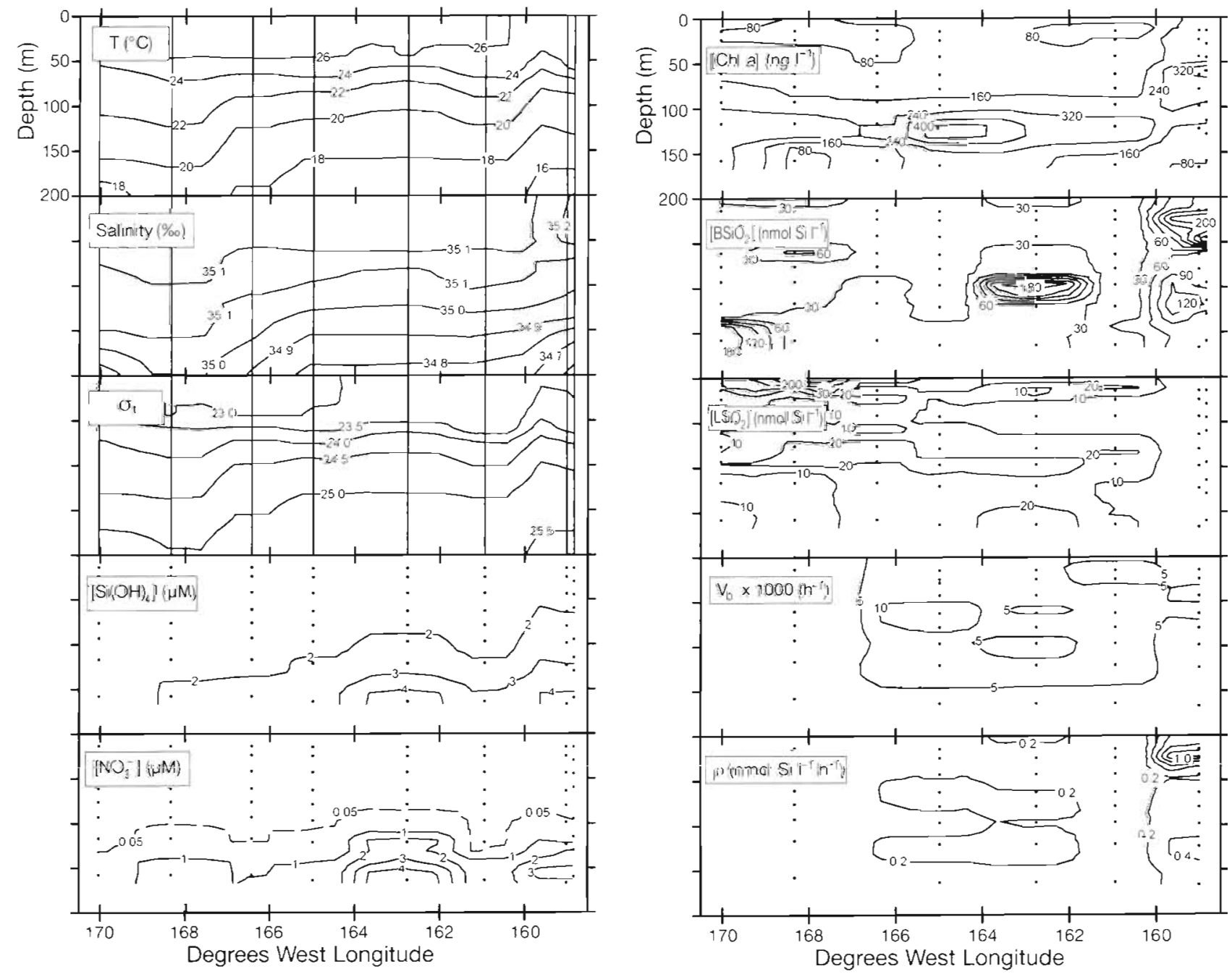

Fig. 2. Contours of physical, chemical and biological properties along the southern transect in 1995 . $\sigma_{1}$ : density; [BSiO 2$]$ : biogenic silica concentration; $\left[\mathrm{LSiO}_{2}\right]$ : lithogenic silica concentration; $V_{\mathrm{b}}$ : specific biogenic silica production rate; $p$ : silica production rate. Sampling locations and depths for physical parameters are indicated by the vertical bars and by dots for all other parameters. Note change in contour interval denoted by dashed contours in the plots of nitrate and lithogenic silica concentrations

isopycnal also occurred in the northern transect between 163 and $168^{\circ} \mathrm{W}$ (Fig. 3). In 1996, the 25.5 isopycnal was consistently present in the upper $200 \mathrm{~m}$ between Hawaii and the California Current (Fig. 4), bringing higher nutrient water into the upper $200 \mathrm{~m}$ compared with the previous year.

\section{Nutrient distributions}

Surface silicic acid concentrations were 0.9 to $1.3 \mu \mathrm{M}$ along the southern 1995 transect at ca $25.5^{\circ} \mathrm{N}$ (Fig. 2) and were slightly higher $(1.1$ to $1.5 \mu \mathrm{M})$ along the northern 1995 transect at ca $27.7^{\circ} \mathrm{N}$ (Fig. 3). Surface silicic acid concentrations along 30 to $31^{\circ} \mathrm{N}$ in 1996 were 2.0 to $3.0 \mu \mathrm{M}$ (Fig. 4). Venrick (1979) also noted that pattern of increasing silicic acid concentration in surface waters with latitude in the central North Pacific. Silicic acid concentrations in subsurface waters $(>80 \mathrm{~m})$ also increased from the most southern to the most northern transect, paralleling the poleward shoaling of isopycnals (Figs. 2 to 4 ).

Nitrate in the upper 60 to $80 \mathrm{~m}$ was severely depleted to between undetectable levels ( $<2 \mathrm{nM})$ and $50 \mathrm{nM}$ along all transects (Figs. 2 to 4 ). Nitrate concentrations rose sharply below the $1 \%$ light depth to 1-4 $\mu \mathrm{M}$ in 1995 and to $2-9 \mu \mathrm{M}$ along the 1996 transect. Elevated nitrate and silicic acid concentrations were observed in the lower euphotic zone associated with the localized doming of isopycnals (Figs. 2 to 4 ). The ratio of $\left[\mathrm{Si}(\mathrm{OH})_{4}\right]:\left[\mathrm{NO}_{3}{ }^{-}\right]$below the euphotic zone $(180$ to $200 \mathrm{~m}$ ) was close to Redfield proportions (i.e. the mole ratio of silicic acid to nitrate was about 0.8 ; Brzezinski 1985) along all transects. $\left[\mathrm{Si}(\mathrm{OH})_{4}\right]:\left[\mathrm{NO}_{3}{ }^{-}\right]$ratios 

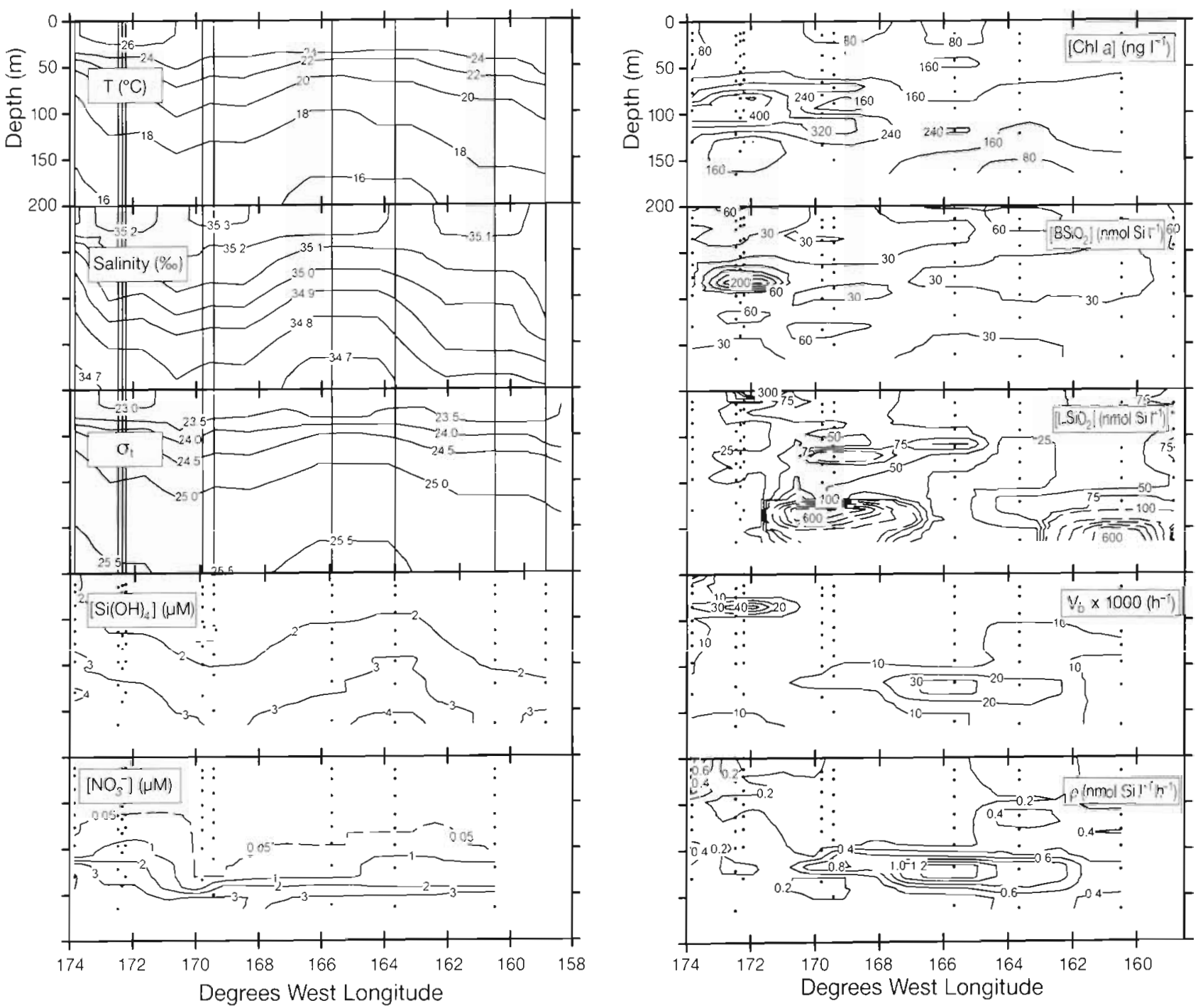

Fig. 3. Contours of physical, chemical and biological properties along the northern transect in 1995 . Sampling depths and locations indicated as in Fig. 2. Note change in contour interval denoted by dashed contours in the plots of nitrate and lithogenic silica concentrations

increased dramatically in the euphotic zone to values exceeding 100 and occasionally >1000 (data not shown), indicating the preferential consumption of nitrate.

\section{Particulate silica and chlorophyll a concentrations}

Biogenic silica concentrations were generally $<50 \mathrm{nmol} \mathrm{Si} 1^{-1}$ along all 3 transects (Figs. 2 to 4 ). Higher concentrations occurred in subsurface maxima

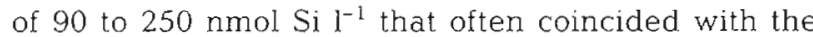
deep chlorophyll maximum. The maximum in biogenic silica between 159 and $162^{\circ} \mathrm{W}$ on the southern 1995 transect associated with the doming of isopycnals (Fig. 2) is noteworthy. Microscopy and visual observa- tions by divers indicated the presence of a diatom bloom dominated by Mastogloia woodiana and Hemiaulus hauckii. [The former is the same taxa reported as a bicapitate Nitzschia sp. by Fryxell et al. (1979)] Epifluorescence microscopy revealed that most $H$. hauckii cells contained Richelia sp. Profiles of biogenic silica concentration obtained on 2 consecutive days in this area showed significantly elevated concentrations compared to all other stations from both cruises (Fig. 5). The depth distributions of biogenic silica concentration and the abundance of $M$. woodiana and $H$. huackii show a tight correspondence, indicating that these 2 species dominated diatom biomass (Fig. 5). The distributions of both biogenic silica and chlorophyll a were spatially more variable in 1996 than in 1995. Localized maxima in biogenic silica concentration 

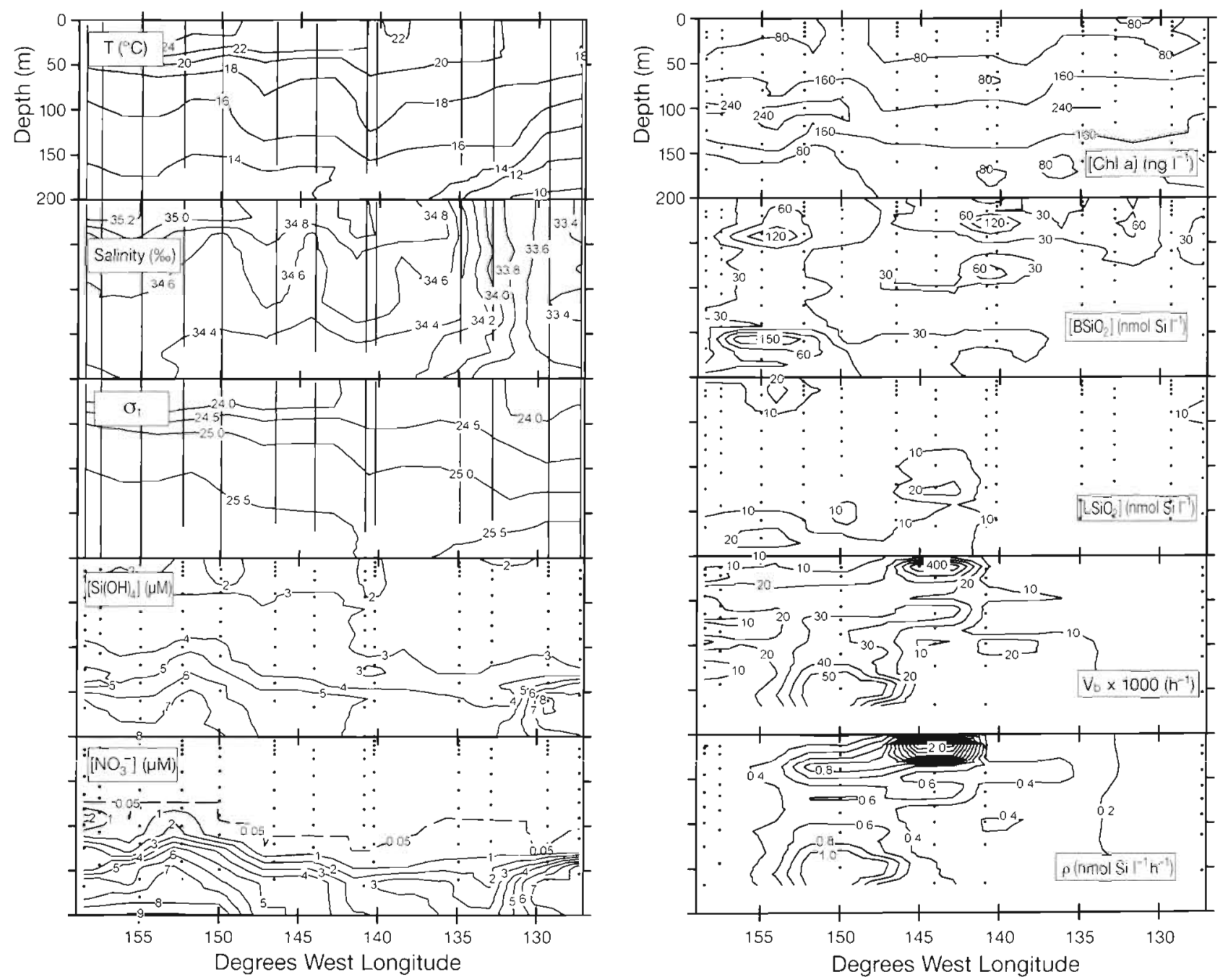

Fig. 4. Contours of physical, chemical. and biological properties along the 1996 transect. Sampling depths and locations indicated as in Fig. 2. Note change in contour interval denoted by dashed contours in the plot of nitrate concentrations

were observed at several locations, but concentrations in those maxima were generally $<150 \mathrm{nmol} \mathrm{Si} \mathrm{I}^{-1}$ (Fig. 4).

Lithogenic silica concentrations were generally $<20 \mathrm{nmol} \mathrm{Si} \mathrm{l}^{-1}$ along the southern section in 1995 with unusually high concentrations (100 to $200 \mathrm{nmol} \mathrm{Si}{ }^{-1}$ ) observed in the upper $20 \mathrm{~m}$ between 166 and $170^{\circ} \mathrm{W}$ (Fig. 2). Concentrations tended to be higher (25 to 50 nmol Si $1^{-1}$ ) along the northern transect. A surface maximum of $304 \mathrm{nmol} \mathrm{Si} \mathrm{l^{-1 }}$ was observed at $172^{\circ} \mathrm{W}$ (Fig. 3). Additional maxima at the base of the euphotic zone were observed at $170^{\circ} \mathrm{W}$ and again at $161^{\circ} \mathrm{W}$ with maximum concentrations of 606 and $618 \mathrm{nmol} \mathrm{Si}$ $\mathrm{I}^{-1}$, respectively (Fig. 3). Lithogenic silica concentrations were lower in 1996 with nearly all values being $<10 \mathrm{nmol} \mathrm{Si}{ }^{-1}$ (Fig. 4).

\section{Silica production rates}

Specific rates of biogenic silica production $\left(V_{\mathrm{b}}\right)$ averaged $0.0075 \mathrm{~h}^{-1}$ (range 0.00046 to $0.045 \mathrm{~h}^{-1}$ ) in 1995 and $0.014 \mathrm{~h}^{-1}$ (range 0.0018 to $0.061 \mathrm{~h}^{-1}$ ) in 1996. Values of $V_{\mathrm{b}}$ tended to be lowest on the southern transect in 1995 and higher on both the northern 1995 and 1996 transects (Figs. 2 to 4,6 ) following the increase in silicic acid concentration with latitude described above. Maxima in $V_{\mathrm{b}}$ occurred both in the surface waters and within the nitracline. Those maxima were not always well correlated with elevated biogenic silica concentrations, but were often observed in or above the high nutrient waters associated with the penetration of the 25.5 isopycnal into the upper $200 \mathrm{~m}$. Estimated doubling times for biogenic silica in those maxima ranged 


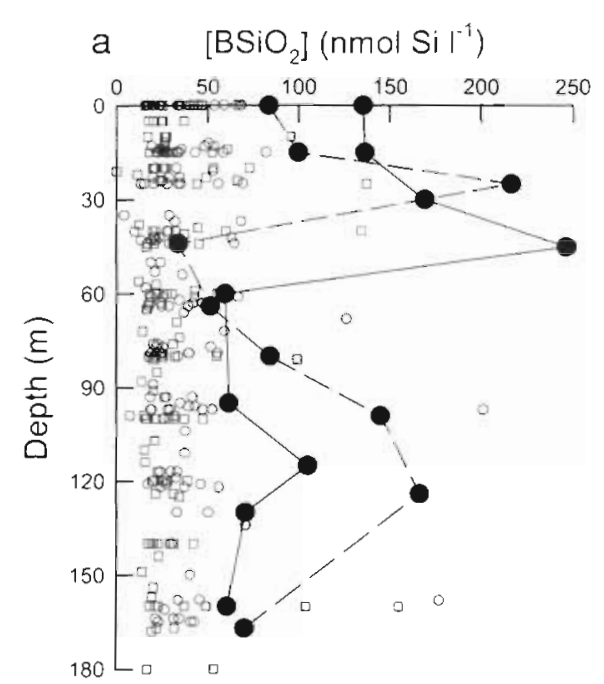

from about 12 to $24 \mathrm{~h}$ and were generally about 3 to $5 \mathrm{~d}$, elsewhere with an overall mean of $3 \mathrm{~d}$.

Silica production rates $(\rho)$ average $0.25 \pm$ 0.22 (SD) nmol Si l-1 $\mathrm{h}^{-1}$ in 1995 (range 0.019 to 1.3 ) and $0.42 \pm 0.45 \mathrm{nmol} \mathrm{Si} l^{-1} \mathrm{~h}^{-1}$ in 1996 (range 0.075 to 2.6 ) with an overall mean for both cruises of $0.30 \mathrm{nmol} \mathrm{Si} \mathrm{l}^{-1} \mathrm{~h}^{-1}$ (Figs. 2 to 4 ). In 1995 a maximum in $p$ occurred on the southern transect associated with the Mastogloial Hemiaulus bloom near $159^{\circ} \mathrm{W}$ (Fig. 2). A band of elevated silica production rates was observed between 162 and $170^{\circ} \mathrm{W}$ just above the nitracline along the northern transect in 1995 coincident with the doming of isopycnals in that region (Fig. 3). In 1996, silica production rates were generally higher in the gyre that in the California Current. Highest rates were observed between 145 and $155^{\circ} \mathrm{W}$ with a strong

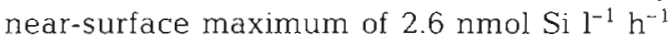
at $144^{\circ} \mathrm{W}$. Values of $\rho$ declined to $0.1-0.3 \mathrm{nmol}$ $\mathrm{Si}^{-1} \mathrm{~h}^{-1}$ in the California Current.

\section{Integrated silica concentrations and production rates}

Integrated biogenic silica concentrations ranged from 1.8 to $18.4 \mathrm{mmol} \mathrm{Si} \mathrm{m}^{-2}$ along all 3 transects with an overall mean of $7.1 \pm 3.0$ $\mathrm{mmol} \mathrm{Si} \mathrm{m}{ }^{-2}$ (SD). The highest values, 16.9

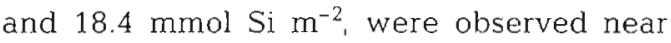
$26^{\circ} \mathrm{N}, 159^{\circ} \mathrm{W}$, where the Mastogloia/Hemiaulus bloom was encountered, but no clear spatial pattern was apparent across the entire study area (Fig. 6). Integrated lithogenic silica concentrations ranged from 0.6 to 21

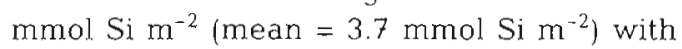

b Cell Abundance (cells $\left.\right|^{-1}$ )
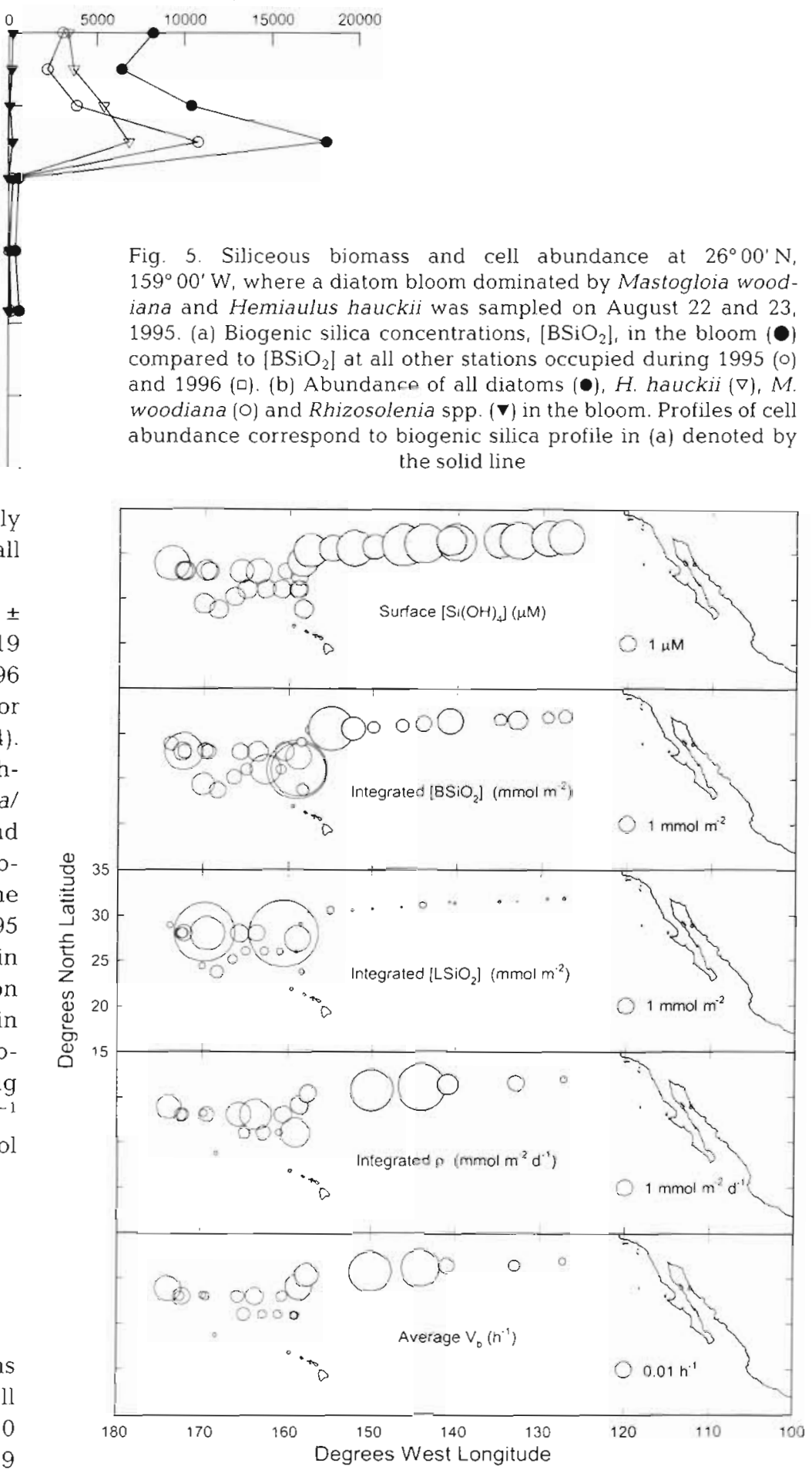

Fig. 6. Bubble plot of surface concentrations of silicic acid $\left[\mathrm{Si}(\mathrm{OH})_{4}\right]_{\text {, }}$ integrated biogenic silica concentrations $\left[\mathrm{BSiO}_{2}\right]$, lithogenic silica concentrations $\left[\mathrm{LSiO}_{2}\right]$, silica production rates $(\rho)$ and the average specific rate of silica production $\left(V_{b}\right)$ between the surface and $0.1 \%$ $I_{0}$. Open and filled symbols correspond to stations occupied in 1995 and 1996, respectively. Properties are proportional to the area of the circle drawn as scaled by the labeled circle in the lower right hand side of each panel 
the largest concentrations occurring to the west of Hawail along the northern transect (Fig. 6). Exceptionally high values were observed at 170 and $161^{\circ} \mathrm{W}$ (Fig. 6) as a result of the strong subsurface maxima in lithogenic silica concentration at those locations (Fig. 3).

Silica production rates obtained from the $12 \mathrm{~h}$ incubations were used to estimate daily integrated silica production rates. Extrapolation from 12 to $24 \mathrm{~h}$ is likely unbiased for average rates as studies examining diurnal variations in silica production rates find no significant difference between average daytime and average nighttime rates, although variability between individual day/night comparisons can be high (e.g. Brzezinski \& Nelson 1989, Nelson \& Brzezinski 1997). Integrated silica production rates were 0.47 to $2.9 \mathrm{mmol} \mathrm{Si} \mathrm{m}^{-2} \mathrm{~d}^{-1}$ (mean $1.24 \mathrm{mmol} \mathrm{Si} \mathrm{m}^{-2} \mathrm{~d}^{-1} ; \mathrm{SD}=0.71, \mathrm{n}=18$ ) with the higher values generally associated with areas of more rapid specific production rates rather than with areas of high siliceous biomass (Fig. 6). The integrated silica production rate in the Mastogloia/Hemiaulus bloom, $1.8 \mathrm{mmol} \mathrm{Si} \mathrm{m}^{-2} \mathrm{~d}^{-1}$, was the second highest for the 1995 cruise and the fourth highest value overall (Fig. 6).

\section{Substrate dependence of silica production}

$V_{b}$ clearly increased in response to additions of silicic acid in 2 of the 3 experiments from 1995 and at all stations in 1996 (Fig. 7). The results at Stn 8 in 1995 were equivocal in that the kinetic curve is essentially flat when the one anomalously high rate at ca $5 \mu \mathrm{M}\left[\mathrm{Si}(\mathrm{OH})_{4}\right]$ is ignored (Fig. 7). Half-saturation constants obtained to the west of Hawail during 1995 were between 0.55 and $2.33 \mu \mathrm{M}$ with values of $V_{\mathrm{m}}$ between 0.008 and $0.01 \mathrm{~h}^{-1}$ (Table 1). Both $K_{\mathrm{s}}$ and $V_{\mathrm{m}}$ values were generally greater in 1996 than in 1995 (Fig. 7) with $K_{\mathrm{s}}$ values from 1.9 to $56 \mu \mathrm{M}$ and values of $V_{\mathrm{m}}$ between 0.02 and $0.28 \mathrm{~h}^{-1}$ (Table 1). At Stns 20, 24 and 28, where the calculated $K_{\mathrm{s}}$ values were $>15 \mu \mathrm{M}$, the relationship between $V_{b}$ and $\left[\mathrm{Si}(\mathrm{OH})_{4}\right]$ was nearly linear (Fig. 7), leading to a poor
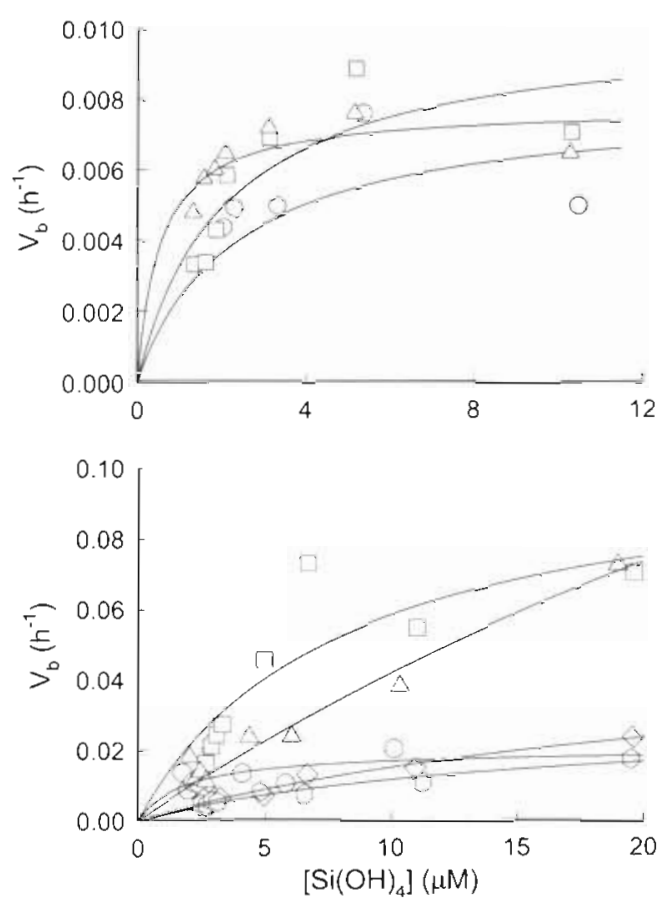

Fig. 7. Results of kinetic experiments. $V_{\mathrm{b}}$ : Specific rates of biogenic silica production. Symbols in upper panel denote experiments conducted during 1995 at $\operatorname{Stn} 8(O), 17(\Delta)$ and 21 $(\square)$. Symbols in lower panel denote experiments conducted in 1996 at Stns $10(0), 14(\square), 20(\Delta), 24(\diamond)$ and $28(0)$. Station locations are given in Table 1 and depicted in Fig. 1

fit to the Michaelis-Menten hyperbola and large uncertainties in both $K_{\mathrm{s}}$ and $V_{\mathrm{m}}$ (Table 1). Despite the large error in the kinetic constants for those experiments, the qualitative result of strong limitation of silica production by the ambient silicic acid concentration is robust. The Mastogloia/Hemiaulus bloom at Stn 21 had the lowest $K_{\mathrm{s}}$ value of all experiments (Table 1).

The kinetic parameters predict that in situ silicic acid concentration restricted silica production rates to between 39 and $71 \%$ (mean $V_{\mathrm{b}} / V_{\mathrm{m}}=50 \%, \mathrm{SD}=18 \%$, $\mathrm{n}=3$ ) of maximum potential rates in 1995 (Table 1). Stronger limitation occurred in 1996 with production

Table 1. Kinetic constants for the concentration dependence of silica production rates on $\left[\mathrm{Si}(\mathrm{OH})_{4}\right]$. Kinetic parameters were used to calculate the ratio of the in situ specific production rate to $V_{\mathrm{m}}, V_{\mathrm{b}} / V_{\mathrm{m}}$, and the initial slope of the kinetics curves, $0.5 V_{\mathrm{m}} / K_{\mathrm{s}}$. Uncertainty terms are standard errors

\begin{tabular}{|c|c|c|c|c|c|c|c|}
\hline Year & Stn no. & Latitude & Longitude & $V_{m}\left(h^{-1}\right)$ & $K_{s}(\mu M)$ & $V_{b} / V_{m}$ & $0.5 V_{\mathrm{m}} / K_{\mathrm{s}}(\times 1000)$ \\
\hline \multirow[t]{3}{*}{1995} & 8 & $28.00^{\circ} \mathrm{N}$ & $172.47^{\circ} \mathrm{W}$ & $0.0079 \pm 0.0027$ & $2.33 \pm 1.97$ & 0.40 & 1.7 \\
\hline & 17 & $25.15^{\circ} \mathrm{N}$ & $166.43^{\circ} \mathrm{W}$ & $0.0101 \pm 0.0020$ & $2.09 \pm 1.06$ & 0.39 & 2.4 \\
\hline & 21 & $25.99^{\circ} \mathrm{N}$ & $159.00^{\circ} \mathrm{W}$ & $0.0077 \pm 0.0007$ & $0.55 \pm 0.26$ & 0.71 & 7.0 \\
\hline \multirow[t]{5}{*}{1996} & 10 & $30.78^{\circ} \mathrm{N}$ & $149.94^{\circ} \mathrm{W}$ & $0.0197 \pm 0.0051$ & $1.89 \pm 1.39$ & 0.48 & 5.2 \\
\hline & 14 & $31.13^{\circ} \mathrm{N}$ & $144.02^{\circ} \mathrm{W}$ & $0.103 \pm 0.030$ & $7.78 \pm 4.53$ & 0.26 & 6.6 \\
\hline & 20 & $31.44^{\circ} \mathrm{N}$ & $140.84^{\circ} \mathrm{W}$ & $0.278 \pm 0.154$ & $56.5 \pm 38.7$ & 0.03 & 2.5 \\
\hline & 24 & $31.53^{\circ} \mathrm{N}$ & $132.85^{\circ} \mathrm{W}$ & $0.0532 \pm 0.0123$ & $25.9 \pm 8.7$ & 0.09 & 1.0 \\
\hline & 28 & $31.88^{\circ} \mathrm{N}$ & $127.26^{\circ} \mathrm{W}$ & $0.0289 \pm 0.0052$ & $15.5 \pm 4.6$ & 0.02 & 0.9 \\
\hline
\end{tabular}


limited to $2-48 \%($ mean $=18 \%, \mathrm{SD}=19 \%, \mathrm{n}=5)$ of maximal potential rates (Table 1). The Mastogloial Hemiaulus bloom assemblage was the least substrate limited $\left(V_{\mathrm{b}} / V_{\mathrm{m}}=0.71\right)$ and best able to exploit low $\left[\mathrm{Si}(\mathrm{OH})_{4}\right]$ (i.e. the bloom assemblage had the kinetic curve with the steepest initial slope, $0.5 V_{\mathrm{m}} / K_{\mathrm{s}}=7.0 \times$ $10^{-3}$; Healey 1980), while those near or in the California Current (Stns 24 and 28) were among the most kinetically inefficient $\left(K_{\mathrm{s}}>15 \mu \mathrm{M}, 0.5 V_{\mathrm{m}} / K_{\mathrm{s}} \leq 1.0 \times\right.$ $\left.10^{-3}\right)$ and the most severely substrate limited $\left(V_{\mathrm{b}} / V_{\mathrm{m}}<\right.$ 0.10 , Table 1).

\section{DISCUSSION}

\section{Nutrient concentrations}

Silicic acid concentrations in the surface waters of the central North Pacific are significantly greater than those present in the one other central gyre where silica cycling has been examined in detail, the Sargasso Sea Surface silicic acid concentrations in the Sargasso Sea are between 0.7 and $0.9 \mu \mathrm{M}$ under stratified conditions compared to the 0.9 to $3.0 \mu \mathrm{M}$ concentrations in surface waters of the central North Pacific. The higher silicic acid concentrations in the surface waters of the central North Pacific are partly the result of the larger gradient in silicic acid concentration beneath the euphotic zone in the Pacific. The $18^{\circ} \mathrm{C}$ water mass between 200 and $400 \mathrm{~m}$ in the Sargasso Sea has a nearly uniform silicic acid concentration of $1.5 \mu \mathrm{M}$ (Brzezinski \& Nelson 1995) compared to the 0.60 to $0.90 \mu \mathrm{M} \mathrm{Si}(\mathrm{OH})_{4}$ concentrations present at the base of the euphotic zone. In contrast, the 1 to $3 \mu \mathrm{M} \mathrm{SirOH})_{4}$ concentrations in the surface waters of the central North Pacific increase to 4 to $8 \mu \mathrm{M}$ by 150 to $200 \mathrm{~m}$ (Figs. 2 to 4 ). The stronger gradients in silicic acid concentration below the euphotic zone in the central North Pacific means that similar rates of vertical mixing introduce more silicic acid into the surface waters there than in the Sargasso Sea.

The high concentrations of silicic acid relative to those of nitrate in the surface waters of the central North Pacific are typical of mid-ocean gyres. That global trend is apparent in historical surveys from the GEOSECS program (e.g. Bainbridge 1980, Craig et al. 1981) that show silicic acid concentrations in the euphotic zone of most central oceans that are readily detectable by conventional automated nutrient analysis, i.e. $>0.5 \mu \mathrm{M} \mathrm{Si}(\mathrm{OH})_{4}$, while nitrate is nearly always undetectable, i.e. $<0.1 \mathrm{MM} \mathrm{NO}_{3}{ }^{-}$. Only a few studies have measured the concentration of both nutrients using more modern methods that have sufficient accuracy and precision that allow a quantitative comparison of their relative concentrations in the surface

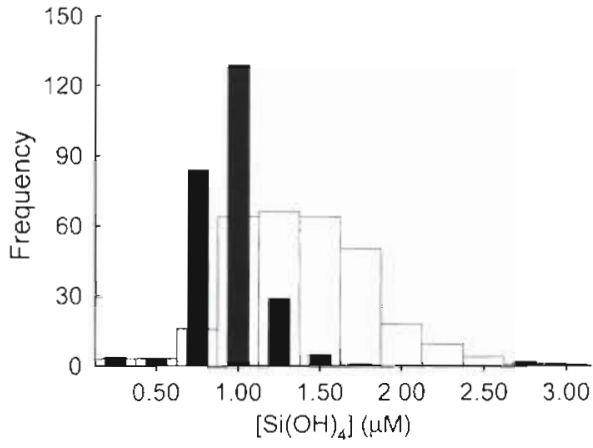

Fig. 8. Frequency histogram of silicic acid concentrations at the HOT (wide white bars) and BATS (narrow black bars) sites off Hawaii and Bermuda, respectively. Data are all measurements in the upper $30 \mathrm{~m}$ from October 1988 to July 1996 at each site portrayed in $0.25 \mu \mathrm{M}$ increments. Labels on the ordinate denote the concentration at the upper extreme of each labeled bin. Data from BATS and HOT data archives

waters above the nutricline. Brzezinski \& Nelson (1995) reported that silicic acid concentrations at the BATS site are consistently between 0.60 and $0.90 \mu \mathrm{M}$ in the upper 70 to $80 \mathrm{~m}$ during stratified periods, while nitrate is typically present at $<30 \mathrm{nM}$ (Lipschultz unpubl.). Blain et al. (1997) also found a relative abundance of silicic acid compared to nitrate in the surface waters of the western equatorial Pacific with $\left[\mathrm{Si}(\mathrm{OH})_{4}\right]$ : $\left[\mathrm{NO}_{3}^{-}\right]>30$ in surface waters. We observed silicic acid concentrations of 1.0 to $1.5 \mu \mathrm{M}$ to the west of Hawaii and 2 to $3 \mu \mathrm{M}$ to the east with corresponding nitrate concentrations in those same areas of $<10 \mathrm{nM}$ giving $\left[\mathrm{Si}(\mathrm{OH})_{4}\right]:\left[\mathrm{NO}_{3}{ }^{-}\right]$ratios of generally $>100$ with some values $>1000$ in surface waters

Surface silicic acid concentrations in mid-ocean gyres are rarely, if ever, depleted to the $<30 \mathrm{nM}$ concentrations that are typical for inorganic nitrogen species. Several years of observations at both the BATS and HOT sites reveal that silicic acid concentrations $<0.25 \mu \mathrm{M}$ account for only $1.2 \%$ of the observations made over several years (Fig. 8). Theoretically, silicic acid could be depleted to nanomolar levels much more often if the silica from diatoms growing on reduced or organic nitrogen sources is exported preferentially to particulate organic nitrogen (PON) via the silica pump (Dugdale et al. 1995). Comparison of total dissolved nitrogen concentrations [TDN] at the HOT and BATS sites ([TDN] generally 2 to $8 \mu \mathrm{M}$ at both sites; data from. BATS and HOT data archives) to those of silicic acid (Fig. 8) does reveal $\left[\mathrm{Si}(\mathrm{OH})_{4}\right]:[T D N]$ ratios $<1$, indicating the preferential removal of dissolved Si from surface waters. (Note that monomeric silicic acid essentially comprises the total dissolved $\mathrm{Si}$ pool as the concentrations of polymeric and organic forms are insignificant in the sea.) The efficiency of the silica pump, however, is generally insufficient to diminish 
silicic acid concentrations to $<0.5 \mu \mathrm{M}$ in the Sargasso and to $<1.0 \mu \mathrm{M}$ in the North Pacific (Fig. 8).

Brzezinski \& Nelson (1995) hypothesized that the persistence of 0.6 to $0.8 \mu \mathrm{M}\left[\mathrm{Si}(\mathrm{OH})_{4}\right]$ in the northwestem Sargasso Sea was due to a threshold concentration of silicic acid that was required to support gross silica production rates that exceed losses due to dissolution. This argument is congruent with culture experiments that show threshold concentrations for net silica praduction by Si-limited diatoms of 0.5 to $1.5 \mu \mathrm{M}$ $\mathrm{Si}(\mathrm{OH})_{4}$ (Paasche 1973). However, ambient concentrations of silicic acid in the surface waters of the central North Pacific are often too high $(>2.5 \mu \mathrm{M})$ for that same argument to apply to that region. A threshold concentration of silicic acid supporting zero net silica production of $>2.5 \mu \mathrm{M}$ has never been observed in culture, indicating that factors in addition to dissolution must be considered.

Grazing on diatoms would increase the threshold silicic acid concentration required to support net silica production. Grazing increases diatom mortality above that caused by the spontaneous dissolution of diatom frustules (Nelson et al. 1976) raising the silicic acid concentration required to achieve positive net growth/ silica production according to the Monod growth kinetics of the diatoms (Tilman 1982). The persistently low concentrations of biogenic silica in the central North Pacific suggest that diatom growth and mortality are generally in approximate balance.

\section{Siliceous biomass}

Biogenic silica concentrations in the central North Pacific are in the lower end of the range observed in more eutrophic waters, but are higher on average than those observed in the Sargasso Sea during the same season. The average integrated biogenic silica concentration in the central North Pacific during July and

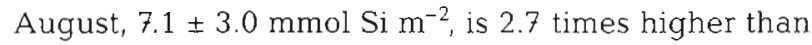
the $4 \mathrm{yr}$ average for the stratified summer-autumn period in the Sargasso Sea $\left(2.7 \pm 0.9 \mathrm{mmol} \mathrm{Si} \mathrm{m}^{-2}\right.$; Brzezinski \& Nelson 1995). This comparison is biased by an apparent strong difference in the seasonal diatom dynamics between these basins. While we observed a significant bloom of diatoms during August (16.9 to $18.4 \mathrm{mmol} \mathrm{Si} \mathrm{m}^{-2}$ ) in the central North Pacific, a mid-summer diatom bloom has never been reported in the Sargasso Sea despite extensive sampling (Brzezinski \& Nelson 1995, Nelson \& Brzezinski 1997). Rather, diatom blooms in the Sargasso occur annually during the late winter/spring with biomass levels similar to those we observed in mid-summer in the central North Pacific (Brzezinski \& Nelson 1995). Including these blooms increases the average integrated bio- genic silica concentration for the Sargasso Sea to $5.0 \pm$ $8.2 \mathrm{mmol} \mathrm{Si} \mathrm{m}^{-2}$, which is close to that observed in the central North Pacific. There are no published data on the seasonality of biogenic silica concentrations in the surface waters of the central North Pacific. However, strong annual peaks in the abundance and export of diatoms at the HOT site during mid-summer rather than during spring (Scharek et al. 1998) corroborate a strong seasonal difference in diatom dynamics between these gyres.

The low diatom biomass in the central North Pacific could result from the limitation of diatom productivity by a nutrient other than silicic acid. The waters of the Subarctic Pacific are thought to be the source of the shallow salinity minimum in the central North Pacific (Reid 1973, Yuan \& Taley 1992). The Subarctic Pacific waters to the north and the equatorial waters to the south are sufficiently iron deficient to limit the growth of diatoms (Martin \& Fitzwater 1988, Coale et al. 1996a, b, Gordon et al. 1997, Landry et al. 1997). One piece of evidence against iron limitation of diatoms in the central North Pacific is the lack of elevated silica production rates where large amounts of lithogenic silica were present in the euphotic zone (Fig. 6). The source of that lithogenic silica is presumably eolian dust that would release iron (Duce \& Tindale 1991). The failure of dust inputs to stimulate silica production was also noted by Nelson \& Brzezinski (1997) for the Sargasso Sea.

\section{Diatom doubling times}

Doubling times estimated from specific rates of silica production suggest that the low diatom biomass of the central North Pacific is growing fairly rapidly. The calculated average doubling time of $3.0 \mathrm{~d}$ is in the lower end of the range abserved in more eutrophic coastal waters (see summary by Brzezinski \& Kosman 1996). The average specific production rate observed in the central North Pacific $\left(0.24 \pm 0.15 \mathrm{~d}^{-1}\right)$ is 1.6 times higher than that reported for the Sargasso Sea $\left(0.15 \pm 0.15 \mathrm{~d}^{-1} ;\right.$ Nelson \& Brzezinski 1997). If left unchecked, the typical diatom biomass encountered in the central North Pacific (ca 50 nmol Si l-1) would deplete the available silicic acid (ca 2 to $3 \mu \mathrm{M}$ ) in $\ln (3.05 / 0.05) / 0.24=<20 \mathrm{~d}$. However, silicic acid depletion is rare in this system (Figs. 2 to 4,8 ), suggesting that a large fraction of silica production is recycled in the surface waters. This is consistent with recent estimates that an average of $50 \%$ of surface silica production is recycled in the surface layer of the sea, with the higher values $(>80 \%)$ being found in warm surface waters comparable to those of the central North Pacific (Nelson et al. 1995). 


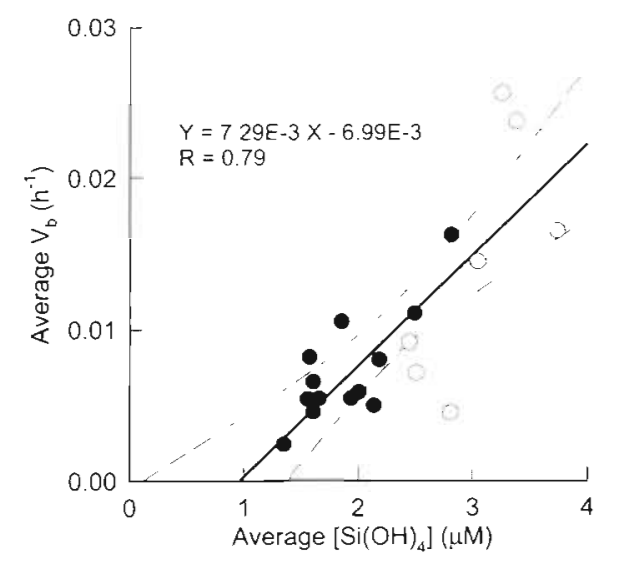

Fig. 9. Average specific rates of biogenic silica production $\left(V_{b}\right)$ between the surface and the $0.1 \%$ light depth versus corresponding average silicic acid concentration over that same depth range. (1) and (O) denote data from 1995 and 1996. respectively. The solid line is the result of a linear regression of the data. Dashed lines are the $95 \%$ confidence interval for the regression line

\section{Si iimitation ố silica production}

Limitation of silica production by low silicic acid availability is both persistent and widespread in this region. Seven of the 8 kinetic experiments conducted in 2 different years at stations distributed over a broad area of the central North Pacific showed clear evidence of substrate limitation of silica production. Those results predict that variations in $V_{\mathrm{b}}$ in situ are driven by changes in ambient $\left[\mathrm{Si}(\mathrm{OH})_{4}\right]$. The data support that prediction. $V_{\mathrm{b}}$ averaged $0.0075 \pm 0.0038 \mathrm{~h}^{-1}$ in the western sector of the central North Pacific where surface silicic acid concentrations were 0.9 to $1.5 \mu \mathrm{M}$, increasing 2 -fold to $0.014 \pm 0.0079 \mathrm{~h}^{-1}$ in the eastern section, where surface silicic acid concentrations increased to 2.0-3.0 $\mathrm{MM}$. Similarly, there is a statistically significant positive correlation between $V_{b}$ and $\left[\mathrm{Si}(\mathrm{OH})_{4}\right]$ in the upper water column (Fig. 9, $\mathrm{r}=0.79$, $t$-test; $\mathrm{p}<0.01$ ). Interestingly, the regression line on Fig. 9 predicts that silica production in situ will cease at a threshold silicic acid concentration $0.96 \mu \mathrm{M}$, which is close to the minimum silicic acid concentration typically found in the surface waters (Figs, 2 to $4,6,8$ ). Mortality from grazing and dissolution in the incubation bottles could produce such a threshold, but the large error in the value of the intercept (Fig. 9) precludes rigorous interpretation of its magnitude.

The values of the kinetic parameters indicate a wide range in the ability of the resident diatoms to exploit. the low concentrations of silicic acid found in the central North Pacific. The utility of kinetic parameters from natural diatom assemblages as indicators of the Si transport characteristics of the resident diatoms is compromised by the presence of multiple species and detrital biogenic silica, the cell-cycle dependence of Si transport (Brzezinski 1992), and the long duration (hours) of typical incubations (McCarthy 1981). These parameters are most useful as biogeochemical indicators of whether ambient silicic acid concentrations suffice to support the siliceous plankton's full capacity for producing biogenic silica. Half-saturation constants for Si uptake from the 1995 cruise are in the same range as the average value for cultured temperate diatoms species, ca. $2.0 \mu \mathrm{M} \mathrm{Si}(\mathrm{OH})_{4}$ (see summary by Nelson \& Tréguer 1992). In contrast, the $K_{\mathrm{s}}$ values observed in 1996 (generally 7 to $56 \mu \mathrm{M}$ ) are among the highest values reported for either natural diatom assemblages or cultured species. The highest $K_{\mathrm{s}}$ values $(>15 \mu \mathrm{M}$ $\mathrm{Si}(\mathrm{OH})_{4}$ Table 1) are suspect as the kinetic curves from which they were derived are nearly linear, producing poor fits to the hyperbolic Michaelis-Menton function. Nevertheless, it is clear from the raw data that the diatom assemblages at those locations were extremely inefficient at utilizing silicic acid as they did not exhibit saturation kinetics between 0 and $20 \mu \mathrm{M} \mathrm{Si}(\mathrm{OH})_{4}$.

Our observation of diatom assemblages with high $K_{\mathrm{s}}$ for silicic acid in oligotrophic waters is not unique. Seven of the 9 kinetic curves obtained by Brzezinski \& Nelson (1996) spanning several seasons in the Sargasso Sea were approximately linear over the 0 to $5 \mu \mathrm{M}$ $\left[\mathrm{Si}(\mathrm{OH})_{4}\right]$ range used in their experiments. Our results show that this near linearity in kinetic curves can extend to much higher substrate concentrations [ca $20 \mu \mathrm{M} \mathrm{Si}(\mathrm{OH})_{4}$ ]. The adaptive significance of such inefficient kinetics in an oligotrophic environment is unknown. Brzezinski \& Nelson (1996) argued that extremely inefficient uptake kinetics induce Si limitation of growth rate and hypothesized that growth rate limitation by Si rather than $\mathrm{N}$ or P provided a competitive advantage in an environment subject to episodic mixing. Their idea was that the elemental and biochemical composition of Si-limited diatoms is more like that of nutrient-replete cells than that seen with either $\mathrm{N}$ or P limitation. Thus, Si-limited cells have more of their metabolic machinery intact to exploit episodic mixing events that suddenly increase nutrient availability in the surface waters.

\section{Diatom response to mesoscale processes}

Hayward (1987) argued that the diffusive flux of nutrients across the nutricline of the central North Pacific cannot account for the observed levels of new production and suggested that episodic mixing must fuel a significant fraction of phytoplankton growth. The association of the Mastogloia/Hemiaulus bloom with the doming of isopycnals within the nutricline 
supports that view. The 2 CTD casts made in the bloom on consecutive days both showed the same upward displacement of isopycnals compared to more western stations (Fig. 2). Isopycnal displacements of that magnitude could result from internal waves, but internal wave fields in the open sea are isotropic and thus unlikely to preferentially persist in any one area long enough to cause the observed local increase in phytoplankton biomass. We hypothesize that the shoaling of isopycnals was due to the presence of a cyclonic eddy. Such an eddy could sustain a bloom by lifting denser nutrient-rich waters into the euphotic zone via the doming of isopycnals and by the upward flux of nutrients via isopycnal mixing along upward sloping density surfaces (McGillicuddy \& Robinson 1997).

Observations by Scharek et al. (1998) suggest the bloom that we observed is not a unique event. They observed a diatom bloom also dominated by Mastogloia woodiana and Hemiaulus hauckii the year prior to our observations in July 1994 at Stn ALOHA. $\left(22^{\circ} 22^{\prime} \mathrm{N}, 158^{\circ} 00^{\prime} \mathrm{W}\right)$ not far south of the bloom we observed in $1995\left(26^{\circ} 00^{\prime} \mathrm{N}, 158^{\circ} 00^{\prime} \mathrm{W}\right)$. Sediment trap studies at the HOT site show an annual pulse of POC export in summer in association with a large flux of diatoms (R. Scharek \& D. Karl pers. comm.). If sufficiently frequent, such mid-summer blooms could be quantitatively important to regional silica and carbon cycling.

The bloom assemblage had the lowest $K_{\mathrm{s}}$ for silicic acid uptake and the kinetic curve with the steepest initial slope $\left(0.5 V_{\mathrm{m}} / K_{\mathrm{s}}\right.$; Table 1$)$. This ability to efficiently exploit low silicic acid concentrations may have provided Mastogloia woodiana and Hemiaulus hauckii with a competitive advantage over other diatoms. The growth of $H$. hauckii may have been further aided by the presence of the known N-fixing endosymbiont, Richelia sp. inside most $H$. hauckii cells. Several biogeochemical indicators suggest that nitrogen fixation may have increased in the central North Pacific in recent years (Karl et al. 1997). It is interesting to speculate that blooms of diatoms with $\mathrm{N}$-fixing endosymbionts have contributed to that trend. This hypothesis is supported by observations that Hemiaulus spp. often dominate summer diatom blooms in the central North Pacific (Venrick 1974, Villareal et al, 1996) with cell abundances of up to 6000 cells $1^{-1}$ (Villareal et al. 1996) and by the direct experimental demonstration of nitrogen fixation by the Hemiaulus-Richelia symbiosis (Villareal 1991).

\section{Diatom primary productivity}

Our results imply that diatoms carry out a surprisingly large fraction of primary production in the central
North Pacific. The average integrated primary production at the HOT site between October 1988 and November 1993 is $450 \mathrm{mg} \mathrm{C} \mathrm{m}^{-2} \mathrm{~d}^{-1}=37.5 \mathrm{mmol} \mathrm{C} \mathrm{m}{ }^{-2}$ $\mathrm{d}^{-1}$ (Karl et al. 1996). Values close to that long-term average were measured at the HOT site in August 1995 (436 $\mathrm{mg} \mathrm{C} \mathrm{m}{ }^{-2} \mathrm{~d}^{-1}$ ) and July 1996 (446 $\mathrm{mg} \mathrm{C} \mathrm{m}^{-2}$ $\mathrm{d}^{-1}$, data from the HOT data archive). Using a diatom Si:C mole ratio of 0.13 (Brzezinski 1985) and our average integrated silica production rate $(1.24 \mathrm{mmol} \mathrm{Si}$ $\mathrm{m}^{-2} \mathrm{~d}^{-1}$ ) yields an estimated diatom carbon productivity of $9.5 \mathrm{mmol} \mathrm{C} \mathrm{m} \mathrm{m}^{-2} \mathrm{~d}^{-1}\left(=114 \mathrm{mg} \mathrm{C} \mathrm{m}^{-2} \mathrm{~d}^{-1}\right)$. This is a conservative estimate as silicic acid limitation of silica production appears widespread in this region, which would lower $\mathrm{Si}$ :C mole ratios for the diatom assemblages studied from the value for nutrient-replete cells used in this calculation. We estimate that diatoms account for $9.5 / 37.5=25 \%$ of total primary production during mid-summer in the central North Pacific. This value is close to the estimate by Nelson \& Brzezinski (1997) that diatoms account for 13 to $26 \%$ of primary production in the Sargasso Sea and to the estimate by Blain et al. (1997) that diatoms account for an average of $34 \%$ of carbon fixation in the equatorial Pacific. The contribution of diatoms to primary production in the central North Pacific may be less during other seasons as diatoms are paradoxically most abundant during summer in this region (Scharek et al. 1998).

\section{Coupling of $\mathrm{N}$ and Si cycles}

Silicic acid and nitrate concentrations covary in about a 1:1 mole ratio in the nutricline for concentrations up to about $15 \mu \mathrm{M}$ corresponding to a depth of

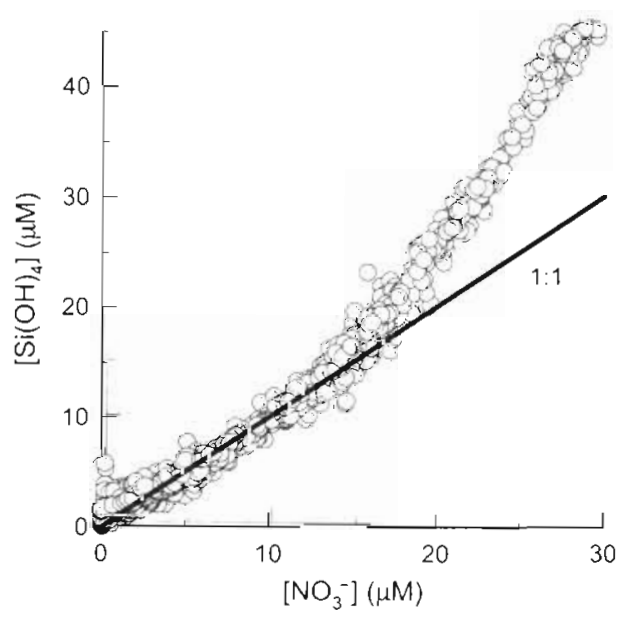

Fig. 10. Plot of nitrate versus silicic acid concentrations in the upper $4500 \mathrm{~m}$ at the US JGOFS HOT site. The line drawn depicts a perfect 1:1 relationship. Data from the HOT data archive 
about $500 \mathrm{~m}$ (Fig. 10), suggesting that vertical mixing will supply about equal amounts of silicic acid and nitrate to the surface layer. However, the concentration gradient of silicic acid through the nutricline is about $7 \%$ less than that of nitrate because of the greater silicic acid concentrations $(1$ to $3 \mu \mathrm{M})$ in the surface waters compared to those of nitrate $\left(<0.05 \mu \mathrm{M}_{i}\right.$ Figs. 2 to 4$)$. The resulting $\mathrm{Si}(\mathrm{OH})_{4}: \mathrm{NO}_{3}{ }^{-}$supply rate ratio of ca 0.9 is nearly the same as the Si: $\mathrm{N}$ mole ratio of 0.8 in nutrient-replete diatoms (Brzezinski 1985). The implication is that the observed net consumption of the silicic acid supplied to surface waters requires that diatoms take up an amount of nitrate equal to the total new production in the system. That is likely an overestimate, but the contribution of diatoms to new and export production is likely considerable.

A significant amount of new production by diatoms may occur at the base of the euphotic zone. Maxima in $V_{b}$ and $\rho$ were observed within the nitracline along the northern transect at $166^{\circ} \mathrm{W}$ in 1995 (Fig. 3) and at ca $151^{\circ} \mathrm{W}$ in 1996 (Fig. 4). Subsurface maxima in $V_{\mathrm{b}}$ at the base of the euphotic zone have also been reported in the Sargasso Sea (Brzezinski \& Kosman 1996, Nelson \& Brzezinski 1997), suggesting that this may be a common feature of open ocean diatom dynamics.

High levels of new production by diatoms do not necessarily mean that diatoms account for high levels of PON export from the euphotic zone. The ratio of biogenic silica to organic nitrogen in sinking remnants of diatoms is a function of the relative rates of biogenic silica and diatom-derived PON turnover in the surface waters (Dugdale et al. 1995, Brzezinski et al. 1997). Both biogenic silica and particulate nitrogen are recycled extensively in the surface waters of midocean gyres. Estimates from the Sargasso Sea indicate that $80 \%$ of the biogenic silica produced in surface waters is recycled in the upper $150 \mathrm{~m}$ (Brzezinski \& Nelson 1995) and $f$-ratios in the open sea are generally 0.3 or less (Eppley \& Peterson 1979). Measures of silica dissolution:production rate ratios are fairly specific to diatoms, but quantifying the turnover of diatom-derived PON amidst the signal from the more abundant picoplankton is difficult. At one extreme, diatom new and export production can be severely decoupled with all organic matter being stripped from diatoms in the surface waters. The export of the resulting empty diatom frustules contributes nothing to the flux of organic material, even if diatoms consume most of the nitrate supply. The contribution of diatoms to the export of particulate organic matter is greatest when intact diatoms sink to depth (Michaels \& Silver 1988).

There is indirect evidence that a significant fraction of diatom new production in the open sea is exported as diatom PON. At the HOT site the export of POC and
PON recorded in deep sediments traps often coincides with the export of biogenic silica from the surface waters (D. Karl pers. comm.), with a similar observation reported from the equatorial Pacific upwelling zone (Honjo et al. 1995). A striking piece of direct evidence was reported by Smith et al. (1996) who found intact, pigment-containing diatoms forming a visible layer in the sea floor at $>4000 \mathrm{~m}$ beneath the equatorial Pacific, indicating the rapid export of a diatom bloom.

\section{Role of mid-ocean gyres in global silica budget}

Mid-ocean gyres are severely undersampled relative to silica production. The central North Pacific is only the second mid-ocean gyre where studies of silica cycling have been conducted However, the picture emerging from our study in the central North Pacific, and from others in the Sargasso Sea, is that silica production in central gyres is considerable in global terms. Absolute rates of production are low in these systems. Studies in the Sargasso Sea during non-bloom periods indicate average daily integrated silica production rates of $417 \pm 219$ (SD) $\mu \mathrm{mol} \mathrm{Si} \mathrm{m} \mathrm{m}^{-2}$ $\mathrm{d}^{-1}$ (Nelson \& Brzezinski 1996) and $640 \mu \mathrm{mol} \mathrm{Si} \mathrm{m} \mathrm{m}^{-2}$ $\mathrm{d}^{-1}$ (Brzezinski \& Kosman 1997). The average rate that we observed in the central North Pacific, $1240 \pm 710$ (SD) $\mu \mathrm{mol} \mathrm{Si} \mathrm{m}^{-2} \mathrm{~d}^{-1}$, is 2 to 3 times higher. Even the higher rates in the Pacific are an order of magnitude lower than those observed in more coastal waters where diatoms are typically more abundant (Nelson et al. 1995), but the vast size of mid-ocean gyres causes low rates to translate into globally significant amounts of silica production. At present, the uncertainty about the contribution of mid-ocean gyres to global production is large. Nelson et al. (1995) estimated that mid-ocean gyres account for 9 to $13 \%$ of global silica production using data from the Sargasso Sea gathered by Brzezinski \& Nelson (1995) and Brzezinski \& Kosman (1996). The present study suggests that the contribution of central oceans may be as much as 2 to 3 times higher, with up to $40 \%$ of global silica production occurring in these offshore waters.

Acknowledgements. We thank the captains and crews of the R/V 'Moana Wave' and the R/V 'New Horizon' for their excellent service. George B. Gardner was of great assistance with CTD operations and data processing. Linda O'Bryan, Shelly Adams, William Golden, Rebecca Shipe, Randy Hudson and Christina De La Rocha provided technical assistance. We also thank those involved in the BATS and HOT programs for having data freely available over the world wide web. This work was supported by NSF grants OCE-9401990, OCE9414372 and $O C E-9423561$ 


\section{LITERATURE CITED}

Azam F, Fenchel T, Field JG, Gray JS, Meyer-Reil LA, Thingstad $F$ (1983) The ecological role of water-column microbes in the sea. Mar Ecol Prog Ser 10:257-263

Bainbridge AE (1980) GEOSECS Atlantic Expedition, Vol 2 Sections and profiles. US Government Printing Office, Washington, DC

Blain S, Leynaert A, Tréguer P, Chretiennot-Dinet MC, Rodier $M$ (1997) Biomass, growth rates and limitation of equatorial Pacific diatoms. Deep Sea Res I 44:1255-1275

Broecker WS (1991) The great ocean conveyor. Ocenography 4:79-89

Brzezinski MA (1985) The Si:C:N ratio of marine diatoms: interspecific variability and the effect of some environmental variables. J Phycol 21:347-357

Brzezinski MA (1992) Cell-cycle effects on the kinetics of silicic acid uptake and resource competition among diatoms. J Plankton Res 14:1511-1539

Brzezinski MA, Kosman CA (1996) Silica production in the Sargasso Sea during spring 1989. Mar Ecol Prog Ser 142: $39-45$

Brzezinski MA, Nelson DM (1986) A solvent extraction method for the colorimetric determination of nanomolar concentrations of silicic acid in seawater. Mar Chem 19:139-151

Brzezinski MA, Nelson DM (1989) Seasonal changes in the silicon cycle within a Gulf Stream warm-core ring. Deep Sea Res 36:1009-1030

Brzezinski MA, Nelson DM (1995) The annual silica cycle in the Sargasso Sea near Bermuda. Deep Sea Res 1 42: $1215-1237$

Brzezinski MA, Nelson DM (1996) Chronic substrate limitation of silicic acid uptake rates in the western Sargasso Sea. Deep Sea Res II 43:437-453

Brzezinski MA, Phillips DR (1997) Evaluation of ${ }^{32} \mathrm{Si}$ as a tracer for measuring silica production rates in marine waters. Limnol Oceanogr 42:856-865

Brzezinski MA, Phillips DR, Chavez DR, Dugdale RC, Friederich GE (1997) Silica production in the Monterey California upwelling system. Limnol Oceanogr 42: $1694-1705$

Cho BC, Azam F (1990) Biogeochemical significance of bacterial biomass in the ocean's euphotic zone. Mar Ecol Prog Ser 63:253-259

Coale KH, Fitzwater SE, Gordon RM, Johnson KS, Barber RT (1996a) Control of community growth and export production by upwelled iron in the equatorial Pacific Ocean. Nature 379:621-624

Coale KH, Johnson KS, Fitzwater SE, Gordon RM, Tanner S, Chavez FP, Ferioloi L, Sakamoto C, Rogers P, Millero F, Steunberg P, Nightingale P, Cooper D, Cochlan WP, Landry MR, Constantinou J, Rolwagen G, Travasvina A, Kudela R (1996b) A massive phytoplankton bloom induced by an ecosystems-scale fertilization experiment in the equatorial Pacific Ocean. Nature 383:495-501

Craig H, Broecker WS, Spencer D (1981) GEOSECS Pacific Expedition, Vol 4. Sections and profiles. US Government Printing Office, Washington, DC

Duce RA, Tindale NW (1991) Atmospheric transport of iron and its deposition in the ocean. Limnol Oceanogr 36 $1715-1726$

Dugdale RC, Jones BH, MacIsaac JJ, Goering JJ (1981) Adaptation to nutrient assimilation. In: Platt $T$ (ed) Physiological bases of phytoplankton ecology. Can Bull Fish Aquat Sci 210:234-250

Dugdale RC, Wilkerson FP (1998) Understanding the eastern equatorial Pacific as a continuous new production system regulating on silicate. Nature 391:270-273

Dugdale RC. Wilkerson FP, Minas HJ (1995) The role of the silicate pump in driving new production. Deep Sea Res I 42:697-719

Emerson S, Hayward TL (1995) Chemical tracers of biological processes in shallow waters of North Pacific: preformed nitrate distributions. J Mar Res 53:449-513

Eppley RW, Peterson BJ (1979) Particulate organic matter flux and planktonic new production in the deep ocean. Nature $282: 677-680$

Fryxell GA, Taguchi S, El-Sayed SZ (1979) Vertical distribution of diverse phytoplankton communities in the central Pacific. In: Bischoff JL, Piper DZ (eds) Marine geology and oceanography of the Pacific manganese nodule province. Plenum Publishing Corp, New York, p 203-239

Garside C (1982) A chemoluminescent technique for the determination of nanomolar concentrations of nitrate and nitrite in seawater. Mar Chem 11:159-167

Goldman JC (1988) Spatial and temporal discontinuities of biological processes in pelagic surface waters. In: Rothchild $B$ (ed) Towards a theory on biological-physical interactions. Kluwer Academic Publishers, New York, p 273-296

Goldman JC (1993) Potential role of large oceanic diatoms in new primary production. Deep Sea Res 40:159-168

Gordon RM, Coale KH, Johnson KS (1997) Iron distributions in the equatorial Pacific: implications for new production. Limnol Oceanogr 42:419-431

Hayward TL (1987) The nutrient distribution and primary production in the central North Pacific. Deep Sea Res 34 : $1593-1627$

Healey FP (1980) Slope of the Monod equation as an indicator of advantage in nutrient competition. Microb Ecol 5 $281-286$

Honjo S, Dymond J, Collier R, Manganini SJ (1995) Export production of particles to the interior of the equatorial Pacific Ocean during the $1992 \mathrm{EqPac}$ experiment. Deep Sea Res II 42:831-870

Kamykowski D, Zentara SJ (1985) Nitrate and silicic acid in the world ocean: patterns and processes. Mar Ecol Prog Ser 26:47-59

Karl DM, Christian JR, Dore JE, Hebel DV, Letelier RM, Tupas LM, Winn CD (1996) Seasonal and interannual variability in primary production and particle flux at station ALOHA. Deep Sea Res II 43:539-568

Karl D, Letelier R, Tupas L, Dore J, Christian J, Hebel D (1997) The role of nitrogen fixation in biogeochemical cycling in the subtropical North Pacific Ocean. Nature 388:533-538

Ku TL, Luo S, Kusakabe M, Bishop JKB (1995) ${ }^{228}$ Ra-derived nutrient budgets in the upper equatorial pacific and the role of 'new' silicate in limiting productivity. Deep Sea Res Il 42:479-497

Landry M, Barber RT, Bidigare R, Chai F, Coale KH, Dam HG, Lewis MR, Lindley ST, McCarthy JJ, Roman MR, Stoecker DK, Verity PG, White JR (1997) Iron and grazing constraints on primary production in the central equatorial Pacific: an EqPac synthesis. Limnol Oceanogr 43:405-428

Lewin JC (1962) Silicification. In: Lewin RA (ed) Physiology and biochemistry of algae. Academic Press, New York, p 445-455

Macdonald AM, Wunsch C (1996) An estimate of global ocean circulation and heat flux. Naturc 382:436-439

Martin JH, Fitzwater SE (1988) lron deficiency limits phytoplankton growth in the north-east Subarctic Pacific. Nature 331:341-343

McCarthy JJ (1981) The kinetics of nutrient utilization. In Platt T (ed) Physiological bases of phytoplankton ecology: Can Bull Fish Aquat Sci 210:211-233 
McGillicuddy DJ, Robinson AR (1997) Eddy-induced nutrient supply and new production in the Sargasso Sea. Deep Sea Res $44: 1427-1450$

Michaels AF, Silver MW (1988) Primary production, sinking fluxes and the microbial food web. Deep Sea Res 35: $473-490$

Nelson DM, Brzezinski MA (1990) Kinetics of silicic acid uptake by natural diatom assemblages in two Gulf Stream warm-core rings. Mar Ecol Prog Ser 62:283-292

Nelson DM, Brzezinski MA (1997) Diatom growth and productivity in an oligotrophic mid-ocean gyre: a 3-yr record from the Sargasso Sea near Bermuda. Limnol Oceanogr 42:473-486

Nelson DM, Dortch Q (1996) Silicic acid depletion and silicon limitation in the plume of the Mississippi River: evidence from kinetic studies in spring and summer. Mar Ecol Prog Ser 136:163-178

Nelson DM, Goering SS, Kilham SS, Guillard RRL (1976) Kinetics of silicic acid uptake and rates of silica dissolution in the marine diatom Thalassiosira pseudonana. J Phycol 12:246-252

Nelson DM, Tréguer P (1992) Role of silicon as a limiting nutrient to Antarctic diatoms: evidence from kinetic studies in the Ross Sea ice-edge zone. Mar Ecol Prog Ser $80: 255-264$

Nelson DM, Tréguer P, Brzezinski MA, Leynaert A, Quéguiner B (1995) Production and dissolution of biogenic silica in the ocean: revised global estimates, comparison with regional data and relationship to biogenic sedimentation. Global Biogeochem Cycles 9:359-372

Paasche E (1973) Silicon and the ecology of marine diatoms II. Silicate-uptake kinetics of five diatom species. Mar Biol 19:262-269

Press WH (1992) Numerical recipes in C: the art of scientific computing. Cambridge University Press, New York

Reid JL (1973) The shallow salinity minimum of the Pacific ocean. Deep Sea Res 20:51-68

Scharek R, Latasa M, Karl DM, Bidigare RR (1998) Temporal variations in diatom abundance and downward vertical flux in the oligotrophic North Pacific gyre. Deep Sea

Editorial responsibility: Otto Kinne (Editor).

Oldendorf/Luhe, Germany
Res I (in press)

Sieracki ME, Verity PG, Stoecker DK (1993) Plankton community response to sequential silicate and nitrate depletion during the 1989 North Atlantic spring bloom. Deep Sea Res II 40:213-225

Smith CR, Hoover DJ, Doan SE, Pope RH, DeMaster DJ, Doobs FC, Altabet MA (1996) Phytodetritus at the abyssal seafloor across 10 of latitude in the central equatorial Pacific. Deep Sea Res II 43:1309-1338

Strickland JDH, Parsons TR (1972) A practical handbook of seawater analysis, 2nd edn. Bull Fish Res Bd Can 167

Tilman D (1982) Resource competition and community structure. Princeton University Press, Princeton

Venrick EL (1974) The distribution and significance of Richelia intracellularis Schmidt in the North Pacific Central Gyre. Limnol Oceanogr 19:437-445

Venrick EL (1979) The lateral extent and characteristics of the North pacific Central environment at 35 N. Deep Sea Res 26a:1153-1178

Villareal TA (1991) Nitrogen-fixation by the cyanobacterial symbiont of the diatom genus Hemiaulus. Mar Ecol Prog Ser 75:201-204

Villareal TA, Altabet MA, Culver-Rymsza K (1993) Nitrogen transport by vertically migrating diatom mats in the North Pacific Ocean. Nature 363:709-712

Villareal TA, Woods S, Moore JK, Culver-Rymsza K (1996) Vertical migration of Rhizosolenia mats and their significance to $\mathrm{NO}_{3}{ }^{-}$fluxes in the central North Pacific gyre. J Plankton Res 18:1103-1121

Waterbury JB, Watson SW, Guillard RRL, Brand LE (1979) Widespread occurrence of a unicellular, marine, planktonic, cynobacterium. Nature 277:293-294

Welschmeyer NA (1994) Fluorometeric analysis of chlorophyll $a$ in the presence of chl $b$ and phaeopigments. Limnol Oceanogr 39:1985-1992

Yoshizumi K, Aoki K, Matsuoka T, Asakura S (1985) Determination of nitrate by a flow system with a chemoluminescent NOx analyzer. Anal Chem 57:737-740

Yuan X, Taley LD (1992) Shallow salinity minimum in the North Pacific. J Phys Oceanogr 22:1302-1316

Submitted: November 7, 1997; Accepted: March 17, 1998

Proofs received from author(s): May 22, 1998 